\title{
E-Commerce Strategy in Driving Sharing Economy in Culinary Industry
}

\author{
Erwan Sudiwijaya ${ }^{1, a)}$ Kuskridho Ambardi ${ }^{2)}$ \\ ${ }^{1}$ Communication Departement, Universitas Muhammadiyah Yogyakarta, Indonesia \\ a)author correspondence: erwansudiwijaya@umy.ac.id \\ ${ }^{2}$ Communication Department, Universitas Gadjah Mada, Yogyakarta, Indonesia
}

DOI: https://doi.org/10.18196/ $/ \mathrm{km} .131050$

Article Info

Article history:

Received 30 Jun 2020

Revised 05 Mar 2021

Accepted 21 Apr 2021

\section{ABSTRACT}

Targeting the Jakarta market, e-commerce catering had emerged to provide practical solutions for routine eating needs. The object in this study was Kulina, which was founded initially as a marketplace in 2015. The initial purpose of its establishment was to drive the sharing economy through co-creation with kitchen and distribution partners to meet the lunch needs of their customers, the employees in Jakarta. The research data was taken by interviews with Digital Marketing Manager and Customer Experience Head and Supervising Delivery. Additionally, observations were conducted on Kulina's digital marketing communication activities on the @ Kulina.id Instagram account during September 2017-January 2018. Document searches were carried out via the internet on Instagram with the keyword \#Kulina and another site containing information about Kulina based on a google search with the keyword Kulina. The study found that customer demand communicated through the website affects complementarity, development of economies of scale, and standardsetting. The information was used to open and develop a sharing economy network and business terms for Partners. Nevertheless, complementarity in Kulina was not only influenced by the meeting of suppliers and demand but also other factors such as traffic jams.

Keywords: Culinary; co-creation; e-commerce; Kulina; sharing economy

\section{ABSTRAK}

Menyasar pasar Jakarta, e-commerce katering mulai bermunculan untuk memberikan solusi praktis kebutuhan makan secara rutin, Objek dalam penelitian ini adalah Kulina yang berdiri pada tahun 2015 dengan konsep berbeda, yaitu marketplace untuk menggerakan ekonomi berbagi melalui cocreation bersama mitra dapur dan mitra distribusi yang memenuhi kebutuhan makan siang pelanggan karyawan di pusat bisnis Jakarta. Metodologi dalam penelitian ini. Data penelitian ini diambil dengan mewawancara narasumber Digital Marketing Manager, Customer Experience Head dan Supervising Delivery, observasi pada aktifitas komunikasi pemasaran digital Kulina di akun Instagram @kulina.id selama September 2017 - Januari 2018 dan penelusuran dokumen dilakukan melalui internet pada situs sosial media Instagram melalui pencarian dengan kata kunci \#kulina dan situs lain yang memuat informasi tentang kulina berdasarkan pencarian di google dengan kata kunci kulina. Temuan dari penelitian ini adalah permintaan pelanggan yang dikomunikasikan melalui website mempengaruhi komplementaritas, pengembangan skala ekonomi dan penyusunan standar. Informasi ini digunakan untuk membuka dan mengembangkan jaringan ekonomi berbagi dan penetapan ketentuan bisnis bagi Mitra, walau pada kenyataanya komplementaritas di Kulina tidak hanya dipengaruhi oleh bertemunya pemasok dan permintaan tetapi juga faktor lain seperti kemacetan lalu lintas yang mempengaruhi kualitas komplementaritas setiap hari.

Keywords: Co-creation; e-commerce; ekonomi berbagi; kuliner; kulina 


\section{INTRODUCTION}

Indonesia is fruitful ground for e-commerce growth with $70 \%$ of the population under 40 years old and demographically spread over islands with limited access to retail shops. The presence of $e$ commerce can be an alternative solution for shopping, where e-commerce acts as an information intermediary between buyers and retail stores. Product information becomes a marketed commodity and becomes a solution to reach marketing areas spread across thousands of islands in Indonesia. The rapid growth of the middle class in Indonesia has also increased purchasing power, so it is estimated that Indonesia's gross domestic product will grow by $5.3 \%$ in the next ten years. So, it is not surprising that $52 \%$ of the market e-commerce in Southeast Asia is developing in Indonesia as much as US \$ 46 billion (Pramisti, NQ, Bhaskara, LA, 2018).

E-commerce or electronic commerce is defined as the process of buying, selling, exchanging products, services, and information through computer networks, both intranet and internet (Sims, 2018). Currently, various kinds of product information are marketed through e-commerce easily. Practically, e-commerce as an information broker involving everyone to participate as sellers and buyers at the same time is armed with a smartphone.

Further, this growth stimulates the creativity of its users to create innovation. One of the products that drive the growth of Indonesia's creative economy is a culinary business. Based on a survey conducted by the Indonesian Creative Economy Agency and the Central Bureau of Statistics in 2016, the culinary sub-sector recorded a $41 \%$ contribution to the creative economy's gross domestic product (Salam, F., \& Hasan, 2017)

The growth of $e$-commerce in culinary services in Indonesia is preceded by food delivery services as a solution for the restaurants that do not have delivery services. Foodpanda was present for the first time as a start-up from Germany that spread its wings to Indonesia, followed by GoFood, which acts as an information broker for restaurant partners with a network of tens of thousands of GoJek drivers to run GoFood food delivery services. The rapid growth can be seen from the 37,000 restaurant and restaurant partners that have joined GoFood services and have made it a leader in the food delivery service category in big cities such as Bandung and Jakarta (Pramisti, NQ, Bhaskara, LA, 2018). Ecommerce in culinary in Indonesia is increasingly developing to meet the needs of culinary information ranging from culinary reviews, restaurant searches to catering. Zomato is an information intermediary application that connects culinary lovers and culinary places through search services and reviews of popular culinary places. This start-up has been operating in 23 countries, including Indonesia, and has reviewed 30 thousand restaurants in Jakarta, Bogor, Depok, Tangerang, Bekasi, and Bali. Local e-commerce applications that provide review and search services for restaurants from Indonesia have also started to appear, such as Makan Mana which has been downloaded 100 thousand times, and Foodsessive, both of which have recently reviewed numerous restaurants in Surabaya (Pramisti, NQ, Bhaskara, LA, 2018).

Throughout 2018, the growth of e-commerce in Indonesia reached $78 \%$ and became the highest in the world (Zuraya, 2019). Google Trend recorded growth in demand for food delivery services, increased 15 times from 2015 to 2019, and raised a US \$ 6 billion turnovers. In terms of managing the culinary e-commerce business, its growth has reached six times from 2015 to 2019, with an average growth rate of $57 \%$. The factor supporting this growth is a change in overall consumer behavior to choose to order food rather than coming to the seller's place. Consumers, whether individuals, families, or institutions, prefer to avoid congestion and erratic weather by enjoying messages and eating from home (Putri, 2021).

Targeting the Jakarta market, e-commerce Caterers are starting to emerge to provide practical solutions to everyday eating needs. One of this type of e-commerce is Kulina, founded in 2015 with the concept of marketplace. Kulina acts as a culinary information broker that connects 300 wedding reception catering kitchens from various parts of Jakarta -most of which operated only on Saturdays and Sundays, delivery services, and employees in business centers who need lunch. Kulina sets food prices along with shipping costs at a price range of Rp. 30,000 and can be reduced depending on the number of customers in the building (Triwijanarko, 2018). Based on a pre-research interview with Digital Marketing Manager, Kulina said:

In September 2017, Kulina did a rebranding focusing on selling one-day service one lunch menu. We started orders with 150 orders. The number of orders began to experience a significant increase during November and December by maximizing the internet as a medium of marketing communication and proven to account for $60 \%$ of new customers to 
match the daily orders of its tight competitor, Berrykitchen, at 3,000 orders per day in January 2018. Thomas Dian- Kulina's Digital Marketing Manager

From these points, this research aims to describe Kulina's strategy as e-commerce in driving the sharing economy through co-creation to increase the number of customers after rebranding. The development of internet-based communication technology has triggered digital marketing communication research to promote issues and move netizens. The first research is the promotion of tourism in Yogyakarta, which is driven by user-generated content (UGC). In the study, Amalia and Erwan observe digital marketing communications to promote Jogja tourism and mobilize netizens to interact in the comment column on the @explorejogja Instagram account. The results of this study are the involvement that arises from recommendations, invitations to visit tourist destinations, and reviews about tourist locations (Amalia \& Sudiwijaya, 2020). The next research is Paracrisis and Social Media: Social Network Analysis of Hashtag \#uninstallbukalapak on Twitter. In their research, Acniah Damayanti observes digital marketing communications that drive the hashtag \#uninstallbukalapak. This study shows that the most central actors or accounts in the hashtag network \#uninstallbukalapak are @achmadzaky, @bukalapak, and @jokowi. The discussion topics that appear in the network and amplify \#uninstallbukalapak include the attribution of mistakes to Achmad Zaky, the hashtag association for support for the presidential candidate, and support for Achmad Zaky and Bukalapak (Damayanti, 2020). Previous research took data from the point of view of the communicant, namely followers and netizens. This study, on the contrary, takes a brand manager's point of view to describe e-commerce digital marketing communications to drive the sharing economy in the culinary industry.

Sharing economy is defined as the value obtained from the process of managing neglected assets to be accessible to the community through online media, which leads to a reduced need for ownership of these assets. From this definition, sharing economy can be derived into the main concepts, namely:

1. Value becomes the basis of exchange that creates economic value either by using money or through bartering.

2. Abandoned assets

3. Online access via the internet

4. Community with shared beliefs, social interactions, and values

5. Reduced need for ownership.

The emergence of the sharing economy coincided with the trend of collaborative consumption that marked the waning of overconsumption in the 20th century. Collaborative consumption is driven by the reputation of brands with community-determined choices in shared access. The essence of collaborative consumption is collaboration through internet media to connect with each other, to form communities, and to carry out many interactions (Sundararajan, 2017).

Co-creation describes a new approach to innovation through collaboration between companies, consumers, producers, and interconnected partners. The experience on a product is an accumulation of individual consumer experiences that personalize the use of products according to their needs desires to create the highest value. This consumer customization data will enrich the platform as feedback from consumers. Moreover, the further co-creation stage positively affects customer satisfaction with service companies, customer loyalty, and service expenditures (Grissemann, U.S., \& StokburgerSauer, 2012).

Technology is a key driver of the sharing economy and makes economic activity easier and cheaper by reducing transaction costs. Before the advent of the sharing economy, transaction costs could be very high, requiring direct interaction and making selling prices expensive. Thus, encouraging consumers and suppliers often have to initiate transactions with an agreement in advance. Many of the interactions ended up being canceled due to overpriced costs. Now the internet, smartphones, and other new technologies are addressing this problem (Demary, 2015). In a sharing economy, blockchain technology can create a co-oriented ecosystem (Pazaitis, A., Filippi, PD, \& Kostakis, 2017).

The peer-to-peer business model in the sharing economy is basically a virtual network that connects individual consumers and individual suppliers. This network has six characteristics: complementarity, compatibility, standards, externalities, consumer switching costs, and significant economies of scale. All of these characteristics apply to businesses peer to peer of the sharing economy (Demary, 2015). 
This research will describe how Kulina as e-commerce drives the sharing economy through cocreation with kitchen partners and distribution partners to meet the lunch needs of employee customers in the Jakarta business center through;

1. Complementarity. The shared economic network between platforms, suppliers, and consumers are complementary. The platform will match individual unmet demand with the individual supply available. However, without a supplier providing a common good or service, the sharing economy business platform cannot keep up with demand. On the other hand, without a request, the platform cannot do business with the supplier.

2. Suitability. Suitability is closely related to complementarity, where the supply and demand must be able to move and work in harmony so that the sharing economy network can function.

3. Standard. In the sharing economy, the platform serves as a standard of transactions, including terms of business, payments, and communications.

4. Network externalities. In a sharing economy, the effects of the network do not directly affect the transacting producers, distributors, and consumers. The hallmark of this peer-to-peer business is that the more consumer demands are met on this platform, the more the platform's utility value increases.

5. Consumer Switching Costs. When users are familiar with the standards applied by a platform, it will take a long time to adjust to other platforms. In addition, users will incur search costs to find other platforms with the same service. Every interaction between producers, distributors, and consumers on this platform marks the beginning of the formation of trust. Therefore, the transition of users to the new platform can be initiated with a trust-building process. Research result (Nysveen, H., \& Pedersen, 2014) demonstrated that loyalty to participating and satisfaction is mediated by brand experience.

6. Economies of scale. The costs incurred in sharing economy companies are quite cheap. At the beginning of the operation, it costs enough to create a platform and marketing. Even after the platform programming is complete and the number of users of this platform continues to increase, there are no additional costs that the company must incur. Therefore, the sharing economy company can spread its business wings as widely as possible to reach many consumers and suppliers and make it more flexible to enter the competition.

\section{METHOD}

This study uses a qualitative research method with a descriptive approach. The data were obtained through the process of interviews, observation, and documents analysis. The interview participants in this study were selected based on their involvement in the co-creation process in September 2017 January 2018. Based on these criteria, the sources of this research were the Digital Marketing Manager and Customer Experience Head and Supervising delivery. The interview process was carried out on the Kulina team at the Innovation Factory, Jl. Prof. Herman Yohanes No.1212, Terban, Gondokusuman, Yogyakarta, and the internet on social media sites Instagram on the @ Kulina.id account and searches with the keyword \#Kulina, Kulina's official website, www.kulina.id, and other sites that contain information about Kulina based on a search on google with the keyword Kulina. Observations were made to see Kulina's digital marketing communication activities on the @ Kulina.id Instagram account from September 2017 to January 2018. In addition, document searches were carried out via the internet on the Instagram social media site through searches with the keyword \#Kulina and other sites that contain information about Kulina based on searches on google with the keyword Kulina.

The data in this research is presented by compiling the obtained and reduced data. Data is presented by describing the co-creation process in text and visual form. The text is presented in the form of writing in the form of direct quotations from the speakers' own words and in the form of a narrative, by arranging sentences logically and systematically so that they are easy to read and understand, according to the views used by the subject but focused in the context of the operationalization of the research concept.

Researchers reviewed the co-creation of Kulina's perspective; therefore, the data obtained in this study were transcripts of interviews with informants involved in the process of co-creation. The other documentation data in this study were the news and customer blogs outside of Kulina's official media 
and observation data, namely digital marketing communication activities on Kulina's Instagram. The researcher then reduces this data into a presentation of data that has been grouped based on the research model, then compared with the theoretical basis to produce conclusions and suggestions. In this study, after the data is obtained, the researcher will check the validity using the triangulation method. The researcher then compares the interview information with observations and other documentation sources. The valid data were then analyzed using an interactive analysis model by collecting data from the speakers. After being collected in recorded form, the data is presented in written form or a transcript of the interview results. For all data to focus on research objectives, a process of selection, simplification, and data grouping is required so that the process of co-creation management in Kulina is visible.

\section{RESULT AND DISCUSSION}

Focusing on lunch catering services, Kulina is a technology company that does not have its own kitchen. They work with partner kitchens from caterers scattered throughout Jakarta and its surroundings. Then, Kulina connects customers with the closest partner kitchens and arranges food delivery routes so that the food can arrive on time to the customer's address by the distribution partners. The Kulina CEO explained in their blog that

Kulina's commitment in this business is technically not a caterer, as it does not have its own kitchen. However, although Kulina is not a caterer, it is responsible for the quality of the food. Although it is not a food delivery courier service, it is also responsible for the punctuality of delivery" (Handika, 2017).

As a virtual network, Kulina has six characteristics, namely complementarity, compatibility, standards, externalities, and switching costs, and economies of scale.

\section{Compelementarity}

Kulina arrives as a solution for their customers, mainly employees in Jakarta, dealing with lunch problems. Frequently, lunch break turns into an hour-long competition to overcome the obstacles of queuing for elevators to go up and down and queueing at the food shops. The afternoon break becomes a tiring time to rest. Easy internet access has opened the door to an abundance of information and keeps the target market always faced with multiple choices at all times. This finding laid the foundation for Kulina to create a simple and straightforward product.

Kulina also views the sharing economy network as a pattern of complementary relationships that occur between Kulina as the owner platform, kitchen partners, distribution partners, and customers. For this reason, Kulina seeks to understand the needs of targeted customers, namely employees in Jakarta, then match it with more than 300 partner kitchens of wedding reception catering partners from various parts of Jakarta. These catering partners indeed have good kitchens and are not burdened with expensive rents when they must open shops located in shopping centers (Triwijanarko, 2018). For the delivery from the kitchen to the customer, Kulina works with Ninja Van as a distribution partner. Ninja Van is a start-up that is engaged in the expedition of goods and cooperates with motorbike riders.

Kulina's CEO explained that the recipe for Kulina's success in matching customers and kitchens is the use of algorithms so that costs and distribution times will be more efficient and customers will get food on time at affordable prices (Handika, 2017). 


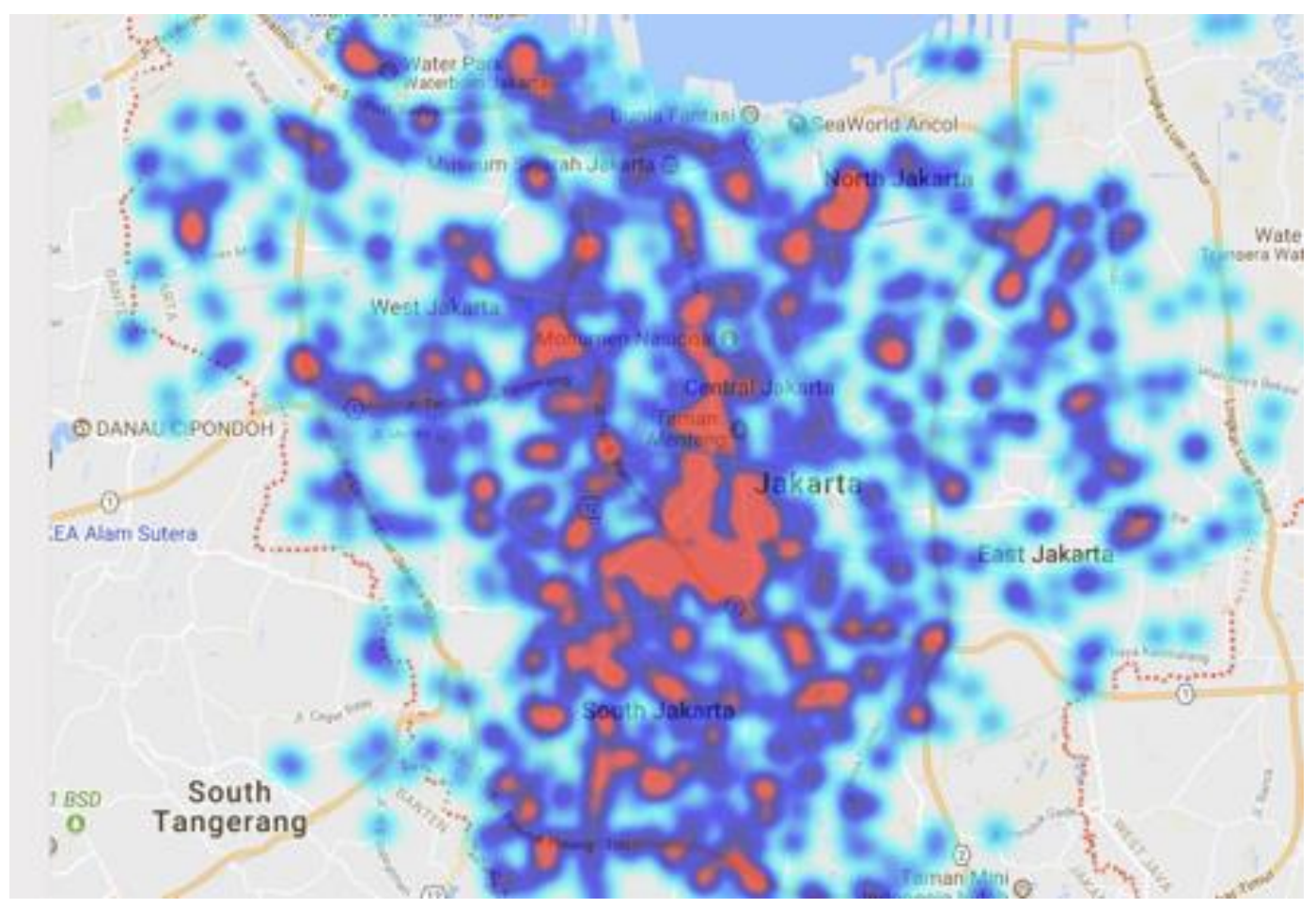

Figure 3 Distribution of Kulina Consumers (Source Handika, AF, 2017, September 26)

The complementarity process of the sharing economy network in Kulina is oriented towards customer demand. The Kulina platform produces a customer demand map that has been used as a basis for consideration to open a sharing economy network in the area.

\section{Conformity}

One of the daily complaints that Kulina receives is the mismatch between the arrival of the food and the predetermined time of delivery. The delays that customers complain about in Kulina can occur due to two things: distribution partners who deliberately fake Proof on Delivery or customers who just pick up food from the package's recipient after 12.00. For this reason, investigations were carried out involving customers and distribution partners. Another complaint received by the Customer Experience team is the mismatch between the menu and what was promised on the website and food received for substandard quality, smaller food sizes, or stale food.

For Kulina's sharing economy network to function through conformity between promises and realization, Kulina's management team works every day to ensure that each menu can be cooked and served according to the menu offered. Then, Kulina makes sure the menu is cooked on time by the partner kitchen so that distribution partners have enough time to deliver to customers precisely at 12.00 .

Every day, the Food Quality Supply and Operation team will check the readiness of each partner kitchen via telegram group boot, which has been set automatically to inquire about the readiness of food every hour from seven o'clock until the cooking deadline at nine o'clock. From each photo sent by the partner kitchen, the Food Quality Supply and Operation team will monitor the composition and readiness of each partner kitchen.

In addition to routine daily coordination, routine weekly coordination with partner kitchens is carried out to ensure the menu for the next week, in the form of a recipe in the form of a description of the recipe and serving rules. Communication between Kulina and partner kitchens is carried out to solve any problems that arise when cooking food. For example, for the raw material constraints that are sometimes difficult for one partner kitchen to find, the Kulina team will help find information from other partner kitchens because partner kitchens are not directly connected. Even if there is a kitchen that is off, Kulina coordinates with other kitchens to replace it.

In addition to the kitchen management, the Kulina team also supervises the delivery of the packages from the kitchen to the customers every day. This routine starts from the deadline for orders 
by the customer, which will be systemically recapitulated and grouped based on the kitchen area; this data is then sent to Ninja Van. In the morning, the Ninja Van coordinator will send the data of PiC and rider for every kitchen. Then, the Supervising Delivery Team will start checking the attendance time of every rider to each $\mathrm{PiC}$. Anticipatory steps will be taken as soon as a rider is not present and will be coordinated to find a replacement. The rider who is late in sending will immediately be notified to the customer.

Delivery delays are not only caused by distribution partners but can also be caused by partner kitchens that have not finished cooking at nine in the morning. In fact, some packaging spaces for partner kitchens are narrow, which makes packing last a long time. All potentially late routes will be informed to customers that their late meal will be waived, and they can prepare to buy another meal for lunch.

On the other hand, each customer can determine where the food will be delivered with a guarantee that the food will be free of charge when the food arrives after 12.00 noon. For this reason, coordination with distribution partners is an important routine to overcome the risk of delays that may arise jointly.

Customers will receive delivery notifications via WhatsApp from Kulina at nine in the morning, so they too can monitor the journey of their food orders (Hidayah, 2018). Delays can also be detected from customer complaints received every day by the Customer Experience team, followed by coordination by the Supervising Delivery team to distribution partners to find out the last position and what obstacles faced in the field.

Evaluation of each delivery rider is always conducted after the delivery limit is completed. All delays are monitored from the time of reporting the completed status from the rider. Not all delays are immediately given non-payment sanctions. Supervising Delivery Team will analyze all packages that are delivered by each rider. In some cases, the delayed completed status can also be caused by weak signals in several buildings in Jakarta. It once happened to the ten packages with the same destination, where the first to seventh packages have the completed status at 10 o'clock, yet the eight to ten packages had the completed status after twelve o'clock and no complaints from customers at that destination. Then, the rider is entitled to a delivery fee for ten packages.

Complaints are not only initiated by the customer but can also be made by distribution partners, especially when distribution partners feel disadvantaged when delivery is on time but reported late by customers because the customers did not directly confirm the delivery so that they get the free consequences for the delivery.

The conformity between customer and kitchen orders can be evaluated through complaints of differences in taste or size of food to customers who subscribe together in a building. From here, the role Customer Experience is necessary to provide an understanding that it is possible when one office customer is served by two partner kitchens. The Food Quality Supply and Operation team will carry out an investigation on the proper kitchen.

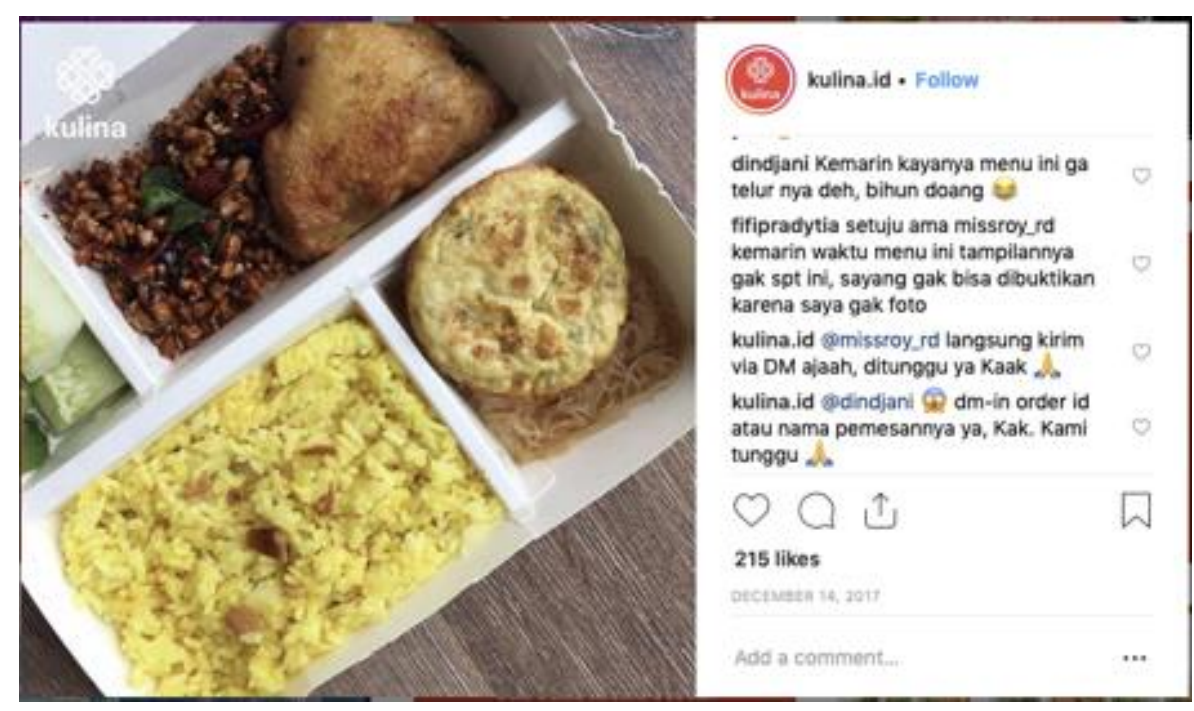

Figure 4 Consumer Complaints on Today's Menu, source: www.instagram.com/Kulina.id 
Complaints on the composition of the food can be seen in the content posted by Kulina on December 14, 2017. In the comment column, the account @ dinjani complained about eggs that were not on the menu today, and @ fifipradyta also regretted that they did not have picture evidence to show that the menu she received was not as complete as in the content. Kulina immediately responded to this complaint by asking for an order ID as material to carry out investigations.

As a collaborative business company, the conformity process in Kulina is challenging to stabilize. This problem will always arise and become more complex as the network of customers and partners grows. Therefore, it has become a routine job in Kulina to initiate complaints from customers and partners, followed up with investigative steps so that the suitability between supply and demand can always be harmonious. Apart from that, the internal team also did the matching in Kulina. After consumers received all the packages, Kulina's internal team conducted a distribution analysis to investigate through cases of delays that were not reported by customers, and then explored the causes and used them as evaluation materials. In addition, Kulina's internal team also analyzed food satisfaction by posting the menu sent today on Instagram so that the customers who feel that they receive food with a different composition could complain in the column comment.

\section{Standard}

For customers, product standardization is a sensitive issue with high risk. Silva felt the inconsistency of the portion standards in Kulina (Silva, 2017). She is a subscriber who finally decides not to continue subscribing because, after one week of subscription, she gets fewer side dishes from the rice.

To maintain product and service standards, every week, Kulina coordinates with partner kitchens to provide a menu guide for one week in the form of recipes and arrangement guidelines. Nevertheless, until now, the portion standard of each Kulina menu is still challenging to monitor, so that it remains the same in each box delivered to the customer.

For distributing partners, Kulina sets a time limit for delivery at noon. The consequence of the delay is that the delivery fee is not paid. So to facilitate monitoring, Kulina decides two types of status that must be renewed by distribution partners, namely transit while the food is in the delivery process and completed if it has arrived and handed over to the customer with proof of the recipient's signature.

The guarantee given by Kulina to customers for the negligence of distribution partners who violated the standards is that the food is uncharged on that day so that orders can be transferred to the next day. The standard of business, transaction, and communication terms in Kulina is oriented towards customer satisfaction, where menu requests, location, and delivery hours from customers are Kulina's basis for establishing business terms for partners. To date, Kulina is still trying to deliver the food menu per the transaction agreement, on time at the location requested by the customer through coordination between Kulina and Partners.

\section{Network Externalities}

Food quality is a focus that is carefully guarded by the Food Quality Supply and Operation team of Kulina. The risk of fatal errors such as spoiled food is of the lowest quality and as much as possible anticipated. For partner kitchens, at the beginning of the contract, the Kulina team informed that the harshest sanction, in this case, was a penalty of three times the price of food purchased from partner kitchens, being banned with a specific time limit, or not being able to partner with Kulina at all.

Customers are often disadvantaged by PoD (Proof on Delivery) counterfeit by distribution partners, where the delivery status has been reported completed at 12.00, but the customer has not got the food. As a reference for assessing partner performance, Kulina makes an assessment standard that is assessed by customers. Every day the Kulina team will send emoji-shaped evaluations mail to customers to assess the quality of the food they enjoy today. This assessment will routinely be recapitulated and shared with kitchen partners every week.

To increase customer engagement in rating, Kulina is promoting its rating system on Instagram. Customers can give ratings via Kulina's website, email, and customer service through live chat on the website and through telephone number 085574677 678. The participation of customers in maintaining the quality and consistency of their lunch is carried out regularly. For instance, Hidayah, E. (Hidayah, 2018) is never absent filling feedback which Kulina sends every day. As a customer, the principle is that the reviews sent will come back again in the form of benefits that he can feel. 


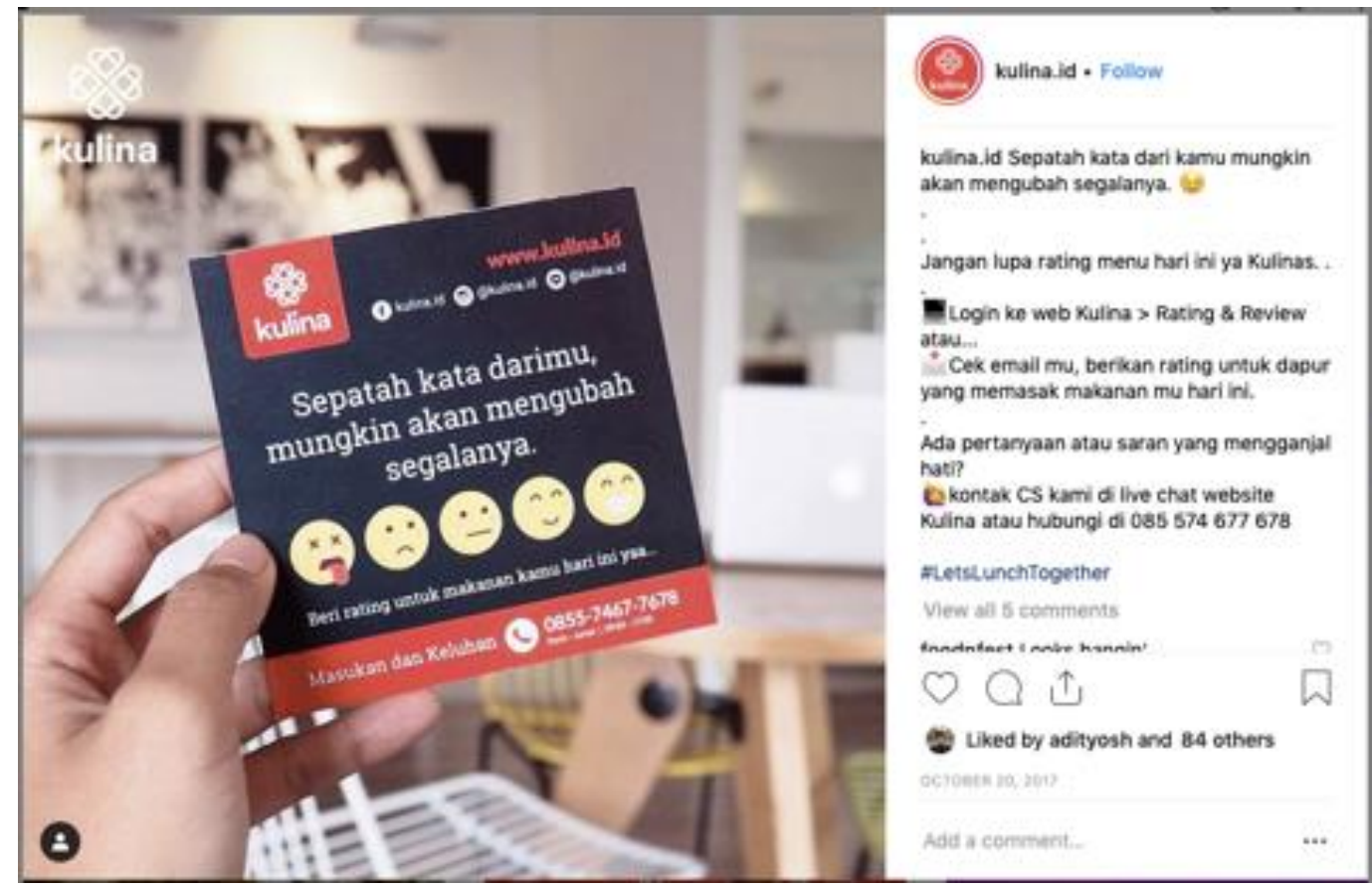

Figure 5 Kulina's Rating System Promotion, source: www.instagram.com/Kulina.id

Kulina distribution partner's assessment is determined by the timeliness of delivery. The distribution partners will update delivery status from transit to travel and completed once the package arrives at the destination by sending proof on delivery. The proof should be attached with the recipient's signature, as an assessment of the customer on the timeliness of the distribution partner.

The Kulina team will start an investigation by finding the name of the distribution partner in charge of delivering the customer, then starting to coordinate with the Ninja Van WhatsApp group to ask for Proof on Delivery from distribution partners. The moment Proof on Delivery is received, Kulina's team will send it to the customer and ask the recipient to confirm the package. Shall the proof on delivery proven to be fake, the distribution partner concerned will get sanctions from Ninja Van.

This assessment will determine the number of partner kitchen orders in the following week because from this assessment, Kulina can find out the capacity of each partner kitchen. To increase the usability value of the Kulina platform, Kulina minimizes the risks by conducting daily evaluations through customer assessments that measure the value of the Kulina platform's usability, as well as assessing the performance of partners because they are the ones who experience the service directly and interact directly with partners.

\section{Consumer Switching Fees}

Kulina provides skip features, allowing customers to pause orders on specific days so that orders can be postponed the next day. Customers take advantage of this feature to postpone orders for several days to a long duration of up to months because they want to try services from other lunch providers. The long-term lag is a challenge for Kulina as it reduces the number of their daily orders.

Kulina's management takes this customer's departure as a time to compare and evaluate the quality of Kulina's food and service. So, they will find a convenient service and can decide what brand to choose for their lunch. Some customers who decided to return to Kulina after a long hiatus realized that Kulina has small things but valuable, which became a reason to resubscribe. The skip feature, which is not found in competitors, makes Kulina felt to be platform flexible for the customer's routine. Another thing that the customer feels is friendly customer service with fast response and solution. Customer complaints are received and responded to effectively, both big and small mistakes, by updating information, apologizing, and giving free orders. These attitudes have also made some of Kulina's complaining customers loyal to Kulina. 
Loyal customers who feel a quick response to their complaints are Stevani, A. (Stevani, 2017), who has been subscribed for four months. She complained when she felt that the side dish was no longer available in his message package. Though the package she chose on the website having a composition of rice + vegetables + meat + complement), she also complained on Twitter. Within 30 minutes, she had received a response from the Kulina Admin team.

The closeness between the customer and Kulina's Customer Experience team has made the communication relationship no longer between brands and customers but has led to relationships peer to peer. This is evident in some of the team members who have resigned from Kulina but still contacted by the customer to inform the date of the delay in ordering and complaints
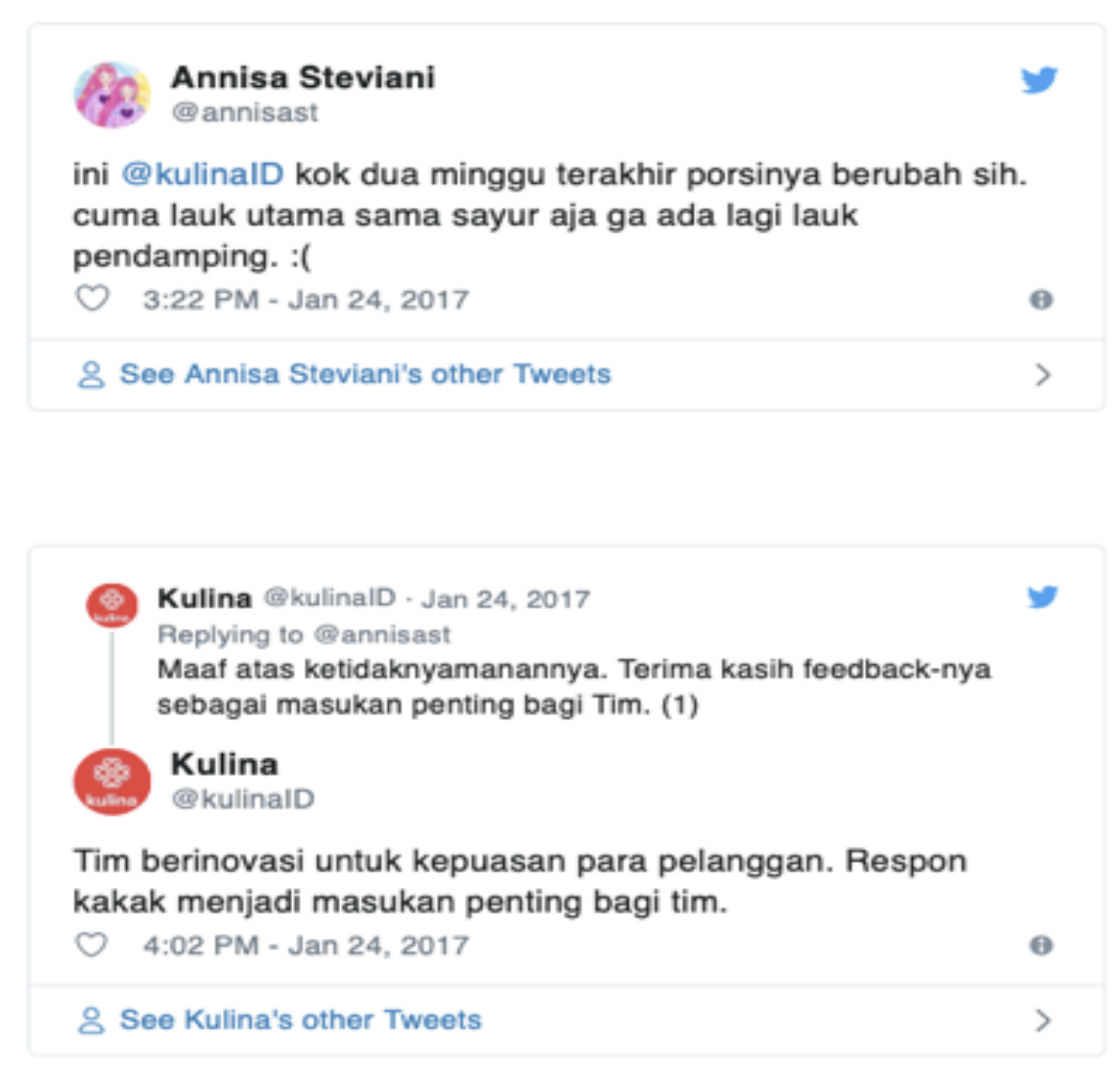

Figure 6 Customer Complaints, Source:(Stevani, 2017)

The ebb and flow of customers is a challenge faced by Kulina's team. Not a few customers resubscribe after customers pause and compare with competitors' lunch services. Little things such as friendly and responsive customer service to provide quick solutions are why customers come back and are loyal. This reason is the foundation of trust from Kulina to build long-term relationships with customers.

\section{Economies of Scale}

Kulina's economic-scale development is focused on Jakarta without any restrictions. Therefore Kulina also invites kitchen owners to become Kulina's kitchen partners through promotions on her Instagram account. However, the high demand to become partner kitchens in one area does not mean that services will be opened for that area. Kulina development is based on requests from customers. Customer demand mapping is carried out periodically by Kulina. Areas that experience growth will have an impact on increasing partner kitchens. An article entitled Efficient Lunch Solutions at Koran Sindo explains Kulina's business growth along with the increase in the number of customers, where currently Kulina uses 14 partner kitchens, and on average, one partner kitchen increases each week (Nararya, 2018). 

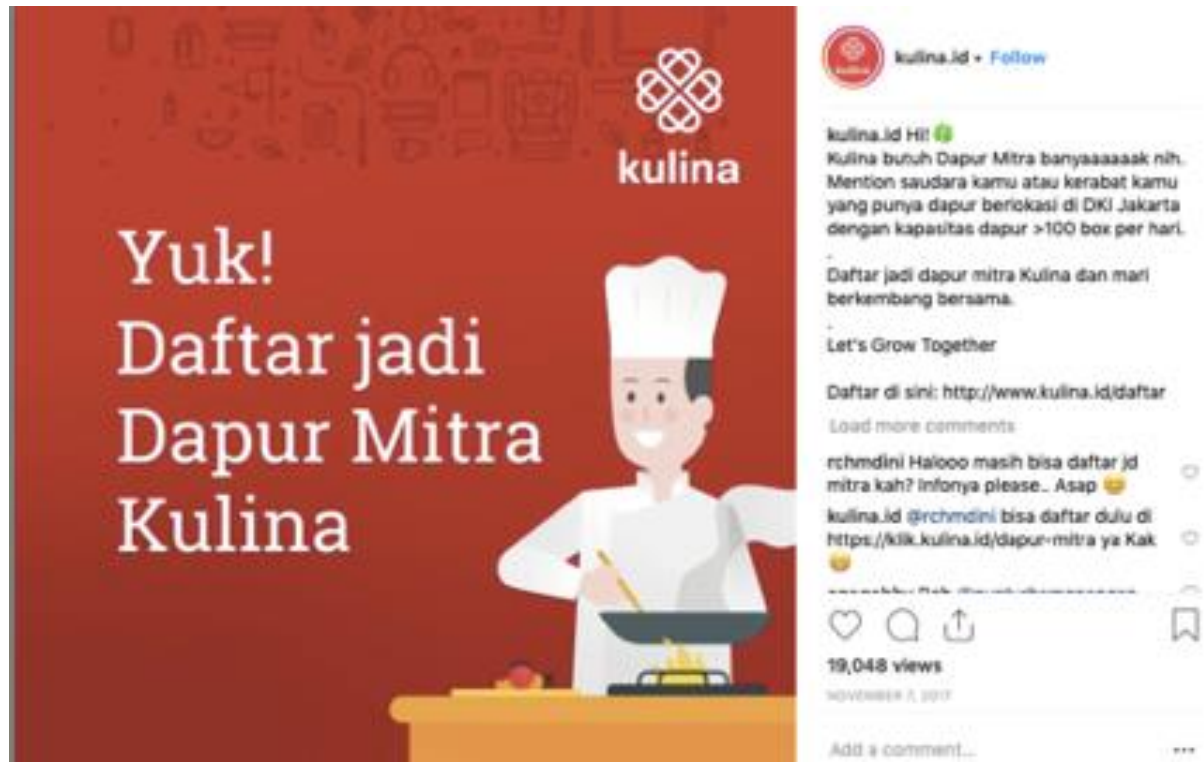

Figure 7. Partner Kitchen Promotion,source: www.instagram.com/Kulina.id

In Kulina, the development of service coverage is carried out with orientation to customer growth in each area. Education to potential customers is needed to maximize customer growth in Jakarta's lunch market while expanding the customer network.

Co-creation in Kulina describes the interconnected collaboration between Kulina, customers, kitchen partners, and distribution partners. The co-creation process started when Kulina created $a$ website that combines algorithms, bott, and management by the Kulina team. Consumers can use this website to customize the order date and delivery address according to their needs. Information and communication technology as the main driver of the sharing economy like Kulina makes economic activities easier and cheaper.

As a virtual network, Kulina's co-creation has six processes: complementarity, compatibility, standards, externalities, costs switching, and economies of scale. The complementarity of a shared economic network works best when suppliers' goods and services meet demand (Demary, 2015). The complementarity process of the sharing economy network in Kulina is oriented towards customer demand at the website, which connects customers with Kulina. This demand data will then form a customer demand map used as a basis for consideration in opening up economic networks in the area. The demand map on Kulina's complementarity is in line with Du, P., \& Chou (2020), whose research shows that the intersection between technology, work, and organization has an important role in cocreation and encouraging the development of a sharing economy.

Closely related to compatibility or complementarity, supply and demand must be able to move and work in harmony (Demary, 2015). Kulina follows up on complaints arising from food delays with investigations to determine whether the fault is on the part of partners, customers, or management. Solutions that emerge are oriented towards the suitability of supply and demand can always be harmonious. Improvements in service that always result in this innovation(Hollebeek, L., \& Rather, 2019) identified as the main drivers of co-creation, satisfaction behavior, advocacy, and customer loyalty intentions.

In the sharing economy business model, the platform functions as a transaction standard covering business terms, payments, and communications (Demary, 2015). The platform actively encourages emotional work practices even in the absence of direct formal control (Bucher, E., Fieseler, C., Lutz, C., \& Newlands, 2020). Standard provisions for business, transactions, and communications in Kulina are oriented towards customer satisfaction. Requests for menu, location, and delivery hours from customers communicated through the website are Kulina's basis for establishing business terms for partners. This two-sided customer relationship framework will help the company take the proper steps to make all actors involved in the process satisfied, loyal and profitable in the long run (Kumar, V., Lahiri, A., \& Dogan, 2018).

Fulfilling consumer demand becomes a standard that will increase the usability value of the peerto-peer business platform (Demary, 2015). Kulina made a rating facility that users can use to assess 
the quality of service and food they get. The rating given by customers is used by Kulina to determine the number of subsequent orders to kitchen partners. Rating facility in a research (Bucher, E., Fieseler, C., Lutz, C., \& Newlands, 2020) is a valuation mechanism that conditions consumers to perform socially desirable behavior during transaction sharing, where open platforms have increased connectivity and sociality among actors (Fehrer, JA, Woratschek, H., \& Brodie, 2018).

The fast handling of complaints made critical customers loyal to Kulina. Responsiveness to testimonials on social media needs to be done quickly because the total number of online customer reviews (OCR volume) is a more popular quality indicator for customers than the average star rating (Hoskins, JD, \& Leick, 2019). The magnitude of the influence of product reviews by customers has a positive effect on the act of sharing 'trust in peers' on this platform (Mmhlmann, 2016) as a form of repeated positive reinforcement, thus creating an emotional bond that encourages commitment (Jalilvand, MR, Salimipour, S., Elyasi, M., \& Mohammadi, 2017) where the relationship among them is mediated by social values, (Wu, W., Wang, H., Wei, C., \& Zheng, nd), entertainment value, and trustworthiness (Cai, S., Phang, CW, Pang, X., \& Zhang, 2017).

The ebb and flow of customers is a challenge faced by Kulina's team. Not a few customers have resubscribed after customers skip and compare with competitors' lunch services. Little things like friendly and responsive customer service to provide quick solutions are their reasons to come back. This reason is the foundation of trust from Kulina to build long-term relationships with customers. This finding is in line with the concept of transferring costs (Demary, 2015), where every interaction that occurs between producers, distributors, and consumers on the platform will mark the beginning of the formation of trust. Therefore, user switching to the new platform can be prevented by the process of building trust.

When the user is familiar with the standards applied by a platform, it will take a long time to adjust to another platform. This dependence is motivated by the economy rather than the supplier of goods (Böcker, L., \& Meelen, 2017). In addition, users will incur search costs to find other platforms with the same service. Cheap costs incurred by a start-up with the sharing economy business model can be seen from the initial capital spent to build the platform. After that, the reach can be widened as widely as possible without any additional costs on the platform (Demary, 2015). In Kulina, the development of service coverage is carried out with orientation to customer growth in each area. The development focus in each of these areas is described by Dreyer, B., Lüdeke-Freund, F., Hamann, R., \& Faccer (2017) as outreach development in a sharing economy that emerges from the trend of collaborative consumption. The development must adapt to the local context, because in a local account, Light, Ann, and Miskelly (2015) emphasized co-organizing to create shared spaces for collaborative use of resources and joint ownership of projects and premises.

\section{CONCLUSION}

Ability internet of things for linking all value chains, impacting the management of collaboration and interaction that takes place horizontally between the platform, kitchen partners, distribution partners, and customers with an essential role in this stage co-creation specified by the customer. Customer requests were communicated via the website, influencing complementarity, developing economies of scale, and standard-setting. This information is used to open and develop a sharing economy network and establish business terms for Partners. Though, in fact, complementarity in Kulina is not only influenced by the meeting of suppliers and demand but also other factors such as traffic jams which affect the quality of complementarity every day.

Complaints that arise are followed up with investigations to determine whether the fault is on the part of partners, customers, or management so that solutions that arise are oriented towards the compatibility of supply and demand to be always harmonious. This process has become a routine in customer management with a variety of new problems every day. The benchmark for measuring network externality underlies the utility value of the Kulina platform and the partners' performance value. Meanwhile, the measurement process is based on customer satisfaction which is communicated through a rating assessment, and customer disappointment which is communicated through complaints. The entire interaction between Kulina with partners and customers and between customers and partners is monitored to ensure the suitability of this sharing economy network so that it can continue to complement and satisfy each other. 


\section{4}

\section{REFERENCES}

Amalia, A., \& Sudiwijaya, E. (2020). Yogyakarta Tourism Promotion using User-Generated-Content Feature. Komunikator, 12(2). https://doi.org/10.18196/jkm.122042

Böcker, L., \& Meelen, T. (2017). Sharing for people, planet or profit? Analysing motivations for intended sharing economy participation. Environmental Innovation and Societal Transitions, 23, 28-39. https://doi.org/10.1016/j.eist.2016.09.004

Bucher, E., Fieseler, C., Lutz, C., \& Newlands, G. (2020). Shaping Emotional Labor Practices in the Sharing Economy*. Theorizing the Sharing Economy: Variety and Trajectories of New Forms of Organizing Research in the Sociology of Organizations, 55-82. https://doi.org/10.1108/s0733-558x20200000066004

Cai, S., Phang, C. W., Pang, X., \& Zhang, Y. (2017). Participation in Collaborative Consumption - A Value Co-creation Perspective. Lecture Notes in Computer Science HCI in Business, Government and Organizations. Supporting Business, 174-189. https://doi.org/10.1007/9783-319-58484-3_14

Damayanti, A. (2020). Paracrisis and Social Media: A Social Network Analysis of Hashtag luninstallbukalapak on Twitter. Komunikator, 12(1). https://doi.org/10.18196/jkm.121032

Demary, V. (2015). Competition in the sharing economy. In IW Policy Paper: Vol. 19. https://www.iwkoeln.de/fileadmin/publikationen/2015/235445/Sharing_Economy_Policy_Pa per.pdf

Dreyer, B., Lüdeke-Freund, F., Hamann, R., \& Faccer, K. (2017). Upsides and downsides of the sharing economy: Collaborative consumption business models' stakeholder value impacts and their relationship to context. Technological Forecasting and Social Change, 125, 87104. https://doi.org/10.1016/j.techfore.2017.03.036

Du, P., \& Chou, H. (2020). Sociomaterial practices for value co-creation in the sharing economy. Information Technology \& People, 33(3), 963-982. https://doi.org/10.1108/itp-10-2018-0477

Fehrer, J. A., Woratschek, H., \& Brodie, R. J. (2018). A systemic logic for platform business models. Journal of Service Management, 29(4), 546-568. https://doi.org/10.1108/josm-02-2017-0036

Grissemann, U. S., \& Stokburger-Sauer, N. E. (2012). Customer co-creation of travel services: The role of company support and customer satisfaction with the co-creation performance. Tourism Management, 33(6), 1483-1492. https://doi.org/10.1016/j.tourman.2012.02.002

Handika, A. F. (2017). Jadi, Kulina itu katering bukan, sih. https://medium.com/@TalkinAndy/jadiKulina-itu-katering-bukan-sih-8a25aa3e3578

Hidayah, E. (2018). Lima Keunggulan catering online Kulina. http://www.mrshidayah.com/2018/03/catering-online-Kulina.html

Hollebeek, L., \& Rather, R. A. (2019). Service innovativeness and tourism customer outcomes. 31(11), 4227-4246. https://doi.org/10.1108/ijchm-03-2018-0256

Hoskins, J. D., \& Leick, R. (2019). Fraud abroad. Journal of Research in Interactive Marketing, 13(2), 249-275. https://doi.org/10.1108/jrim-10-2018-0126

Jalilvand, M. R., Salimipour, S., Elyasi, M., \& Mohammadi, M. (2017). Factors influencing word of mouth behaviour in the restaurant industry. Marketing Intelligence \& Planning, 35(1), 81110. https://doi.org/10.1108/mip-02-2016-0024

Kumar, V., Lahiri, A., \& Dogan, O. B. (2018). A strategic framework for a profitable business model in the sharing economy. Industrial Marketing Management, 69, 147-160. https://doi.org/10.1016/j.indmarman.2017.08.021

Light, Ann and Miskelly, C. (2015). Sharing economy vs sharing cultures? Designing for social, economic and environmental good. Interaction Design and Architecture(s). In Interaction Design and Architecture (Vol. 24, Issue Spring).

Mmhlmann, M. (2016). Digital Trust and Peer-to-Peer Collaborative Consumption Platforms: A Mediation Analysis. SSRN Electronic Journal. https://doi.org/10.2139/ssrn.2813367

Nararya, A. (2018). Solusi makan siang hemat. http://koransindo.com/page/news/2018-0114/0/16/Solusi_Makan_Siang_Hemat

Nysveen, H., \& Pedersen, P. E. (2014). Influences of Cocreation on Brand Experience. International Journal of Market Research, 56(6), 807-832. https://doi.org/10.2501/ijmr-2014-016

Pazaitis, A., Filippi, P. D., \& Kostakis, V. (2017). Blockchain and value systems in the sharing economy: The illustrative case of Backfeed. Technological Forecasting and Social Change, 125, 105-115. https://doi.org/10.1016/j.techfore.2017.05.025 
Pramisti, N. Q., Bhaskara, L. A., \& I. (2018). Belajar dari kegagalan Foodpanda di Indonesia. https://tirto.id/belajar-dari-kegagalan-foodpanda-di-indonesia-bDwh

Putri, C. (2021). Alasan gojek \& GRAB Genjot Bisnis GoFood dan GrabFood. https://www.cnbcindonesia.com/tech/20191007141721-37-104960/alasan-gojek-grab-genjotbisnis-gofood-dan-grabfood

Salam, F., \& Hasan, A. M. (2017). Konsumsi medsos membentuk pola makan generasi Z. https://tirto.id/konsumsi-medsos-membentuk-pola-makan-generasi-z-ctPR

Silva. (2017). Catering harian Kulina. https://silvafauziah.com/2017/01/30/review-catering-harianKulina/

Sims, L. (2018). Building your online store with Wordpress AND woocommerce: Learn to leverage the critical Role e-commerce plays In today?s competitive marketplace. In Building Your Online Store with WordPress and WooCommerce: Learn to Leverage the Critical Role Ecommerc. Springer/Apress.

Stevani, A. (2017). Review Kulina, katering tanpa ribet. https://www.annisast.com/2017/02/reviewKulina-katering-tanpa-ribet.html

Sundararajan, A. (2017). The sharing economy: The end of employment and the rise of crowd-based capitalism. The MIT Press.

Triwijanarko, R. (2018). Meraba masa depan layanan food delivery startup di Indonesia.

Wu, W., Wang, H., Wei, C., \& Zheng, C. (n.d.). Sharing achievement and social entrepreneurial intention. Management Decision, Ahead-of-Print (Ahead-of-Print). https://doi.org/10.1108/md-05-2019-0667

Zuraya, N. (2019). Pertumbuhan E-Commerce Indonesia Tertinggi di dunia. https://www.republika.co.id/berita/ekonomi/korporasi/19/02/27/pnkrfg383-pertumbuhanecommerce-indonesia-tertinggi-di-dunia 